\title{
Whose Fault Is it Anyway? Political Orientation, Attributions of Responsibility, and Support for the War in Iraq
}

\author{
Malte Friese $\cdot$ Shira Fishman · Ruth Beatson • \\ Kelly Sauerwein · Blanka Rip
}

\begin{abstract}
Political orientation has been shown to be a strong predictor of attitudes toward war. Specifically, political conservatism has been associated with increased support for war and with decreased attribution of responsibility for war to one's own government. The present research aims to test whether the relationship between political orientation and support for the war in Iraq is mediated by attributions of government responsibility. In Study 1, survey data showed that the relationship between political orientation and support for the Iraq war was mediated by beliefs about the US government's motivations for the war. Study 2 provided a conceptual replication of the proposed mediation model and extended the findings from beliefs about US government motivations to perceived threat from the pre-war Iraqi government. Study 3 used an experimental paradigm to manipulate perceived threat to show that such beliefs directly affected support for the war. Implications and directions for future research are discussed.
\end{abstract}

This research was initiated at the Summer Institute in Social Psychology (SISP) held in July 2007 at the University of Texas at Austin

M. Friese $(\bowtie)$

Department of Psychology, University of Basel, Missionsstr. 60/62, 4055 Basel, Switzerland e-mail: malte.friese@unibas.ch

\section{S. Fishman}

University of Maryland, College Park, USA

R. Beatson

La Trobe University, Melbourne, Australia

K. Sauerwein

University of California, Davis, USA

B. Rip

University of Quebec, Montreal, Canada 
Keywords Iraq war · Political ideology - Attributions of responsibility · Support for war $\cdot$ Mediation

Since the arrival of US troops in Iraq in March 2003, the war has been highly contested. Thousands of Iraqi and allied troops have died or been wounded in combat. The financial costs of the war, especially in a time of economic difficulty, have been extensive. American taxpayers contributed $\$ 845$ billion directly to the war, and the total cost to the US involvement has been estimated at around \$3 trillion (Reuters, 2008). It is perhaps not surprising, then, that public support for the war in Iraq has declined considerably. In March 2003, shortly after troops were sent to Iraq, polls showed that $75 \%$ of North Americans believed that the invasion was the right decision, and $23 \%$ believed it was a mistake. Five years later, these statistics were considerably changed. In April 2008, polls showed that $63 \%$ of the US population believed that the US had made a mistake in sending troops to Iraq, whereas only $36 \%$ believed that the war was the right course of action (Gallup Poll, 2003, 2008).

Upon closer investigation, diminishing support for the war is only part of the story. A more nuanced view reveals that even before the onset of the invasion, people holding conservative political views were more in favor of the war than were people holding liberal attitudes (Pew Global Attitudes Project, 2003). While both liberals and conservatives have decreased their support for the war, the divide between the two ideologies persists, leading some authors to speak of "separate realities of Republicans and Democrats" (World Public Opinion, 2006). But why should liberals and conservatives support the war to such different degrees?

The current article attempts to address what accounts for this ideological divide. It is assumed that depending on their political orientation people have different views on the question of who was responsible for the war. A set of three studies explores the possibility that these differing attributions of responsibility among liberals and conservatives constitutes a mediating mechanism through which political orientation leads to varying support for the war in Iraq.

\section{The Debate over Political Orientation}

The social science literature provides a rich and decades-long debate about political orientation (or political ideology), its roots, and consequences for people in their political and social lives. Some authors have argued that political orientation, defined as a set of coherent and relatively stable political views, does not exist at all (e.g., Converse, 1964; Lipset, 1960; Shils, 1958). In contrast, other authors have challenged this view and provided evidence that political orientation, as a construct, is a useful mechanism for understanding human behavior (e.g., Jost, 2006; Jost, Nosek, \& Gosling, 2008).

In a recent meta-analysis, Jost, Glaser, Kruglanski, and Sulloway (2003; see also Jost et al., 2007) suggest that varying psychological needs to manage uncertainty, fear, and threat lie at the root of individual differences in political orientation. According to this motivated social cognition perspective, people endorse political views, in part, to 
satisfy these psychological needs and not just because they comply with rational liberal or conservative arguments. In fact, "rational" beliefs and convictions are partially influenced by the desire to fulfill these psychological needs. In line with this reasoning, Jost et al. (2003) identified a number of personality characteristics assumed to facilitate the management of uncertainty, fear, and threat, and predict political conservatism (e.g., authoritarianism, social dominance orientation, need for closure and structure, intolerance of ambiguity). Because individual differences in political orientation can be explained by general personality characteristics, thoughts and behaviors not typically regarded as bearing any systemic relationship to political orientation may be influenced by one's political orientation. For example, Carney, Jost, Gosling, and Potter (2008) found that conservatives (as compared to liberals) tend to own household items associated with orderliness (e.g., ironing boards, laundry baskets) and planning (e.g., event calendars). In contrast, liberals are more likely than conservatives to have items that signal interest in new experiences and diversity (e.g., international maps, greater variety of music CDs, and books).

The personality characteristics associated with differences in political orientation are assumed to develop early in life and are observable even at nursery school (Block \& Block, 2006). Some variance in these psychological needs may be transferred genetically, as recent evidence suggests that political orientation has a genetic component (Alford, Funk, \& Hibbing, 2005). Differences between liberals and conservatives can be traced to the level of information processing (Skitka, Mullen, Griffin, Hutchinson, \& Chamberlin, 2002), neurocognition (Amodio, Jost, Master, \& Yee, 2007), and physiological traits (Oxley et al., 2008). Thus, political orientation appears to reflect deeply rooted and pervasive individual differences in the need to manage uncertainty and threat.

\section{Political Orientation, Support for War, and Attribution Styles}

According to the perspective of political orientation as motivated social cognition, people embrace conservative policies, in part, because these policies often serve to reduce their fear and anxiety (Jost et al., 2003). This view fits well with findings that conservatives support governmental military spending to a greater extent than liberals, presumably because the military may protect against potential future threats (Pratto, Sidanius, Stallworth, \& Malle, 1994). Further corroborating this view, political conservatism has been associated with greater support for war (Agnew, Hoffman, Lehmiller, \& Duncan, 2007; Grote, Frieze, \& Schmidt, 1997), and this result extends to support for the current war in Iraq. Compared to liberals, conservatives were more in favor of military action to end Saddam Hussein's rule before the war started, and they were more likely to continue to think that the war was the right decision after public opinion started to turn (e.g., World Public Opinion, 2006).

Political orientation also affects individual attribution styles. More than liberals, conservatives tend to attribute difficult personal situations such as homelessness and poverty to internal causes (Cozzarelli, Wilkinson, \& Tagler, 2001; Pellegrini, Queirolo, Monarrez, \& Valenzuela, 1997; Sniderman, Hagen, Tetlock, \& Brady, 1986). Similarly, conservatives see wrongdoers as personally responsible and 
accountable for their misdeeds, and consequently recommend harsher punishments for errors. In contrast, liberals tend to focus on situational explanations, suggest less severe punishment, and provide greater assistance to help offenders make amends for, or avoid further, wrongdoing (Carroll, Perkowitz, Lurigio, \& Weaver, 1987; Skitka et al., 2002; Skitka \& Tetlock, 1993). More generally, there is strong evidence that conservatives (vs. liberals) tend to blame members of devalued out-groups and protect members of valued in-groups (Altemeyer, 1998; Jost et al., 2003). For example, compared with liberals, conservatives attributed less responsibility for the 1991 war in Iraq to the US government (Skitka, McMurray, \& Burroughs, 1991).

\section{The Current Research}

Although the constructs of political orientation, attribution styles, and support for war have been investigated separately, no research has explored how these variables interact. The present research used the war in Iraq to explore whether the relationship between political orientation and support for war were in part due to ideological differences in attributions of responsibility. More specifically, we hypothesized that, in comparison to liberals, conservatives would (a) support the war more strongly, (b) attribute less responsibility for the war to the US government, and (c) attribute more responsibility for the war to the pre-war Iraqi government. Importantly, extending previous research, we expected that (d) differing attributions of government responsibility would explain the varying levels of support shown by liberals and conservatives for the war in Iraq. In other words, liberals' and conservatives' attributions of governmental responsibility for the war should, at least in part, account for the effect of political orientation on support for the war.

We investigated this mediation model in three studies. In Study 1, data from a large-scale international public opinion survey were analyzed. Study 2 replicated and extended these findings with a different sample and improved measures of the constructs of interest. Finally, Study 3 investigated the causal mechanism implied by the mediation process: the idea that differences in attributions of government responsibility can systematically influence support for the war.

\section{Study 1}

The Pew Global Attitudes Project offers a series of publicly available opinion surveys on various topics. Data were analyzed from a 2004 survey about the war in Iraq. The survey included an item assessing political orientation and several items representing attributions of governmental responsibility and support for the war in Iraq.

Method

\section{Participants}

The sample comprised 1,390 adults (684 were women) who (a) participated in the 2004 Pew Global Attitudes Project and (b) fulfilled the following criteria: lived in 
the United States, indicated their political orientation, and gave answers to questions that constituted the proposed mediator and the dependent measure (see below). The ages of participants ranged from 18 to 91 years $(M=44.72, S D=17.75)$. Controlling for gender and age did not have any effect on the results and thus, will not be discussed further.

\section{Materials}

All questions were from the Pew Global Attitudes Project (2004), A year after Iraq war. The items selected for analyses measured political orientation, attribution of government responsibility for the war, and support for the war.

Political Orientation The single-item measure of political orientation included a five-point scale ranging from 1 (very conservative) to 5 (very liberal). Participants were asked to indicate where their political views generally fall on this scale. Responses to this item were reverse-scored so that higher scores represented more conservative views.

Attributions of Government Responsibility The following question was used as a proxy for measuring attributions of US government responsibility for the war in Iraq: "Before the war the U.S. and Britain claimed that Iraq had weapons of mass destruction. These weapons have yet to be found. Why do you think they made this claim?" Participants were asked to choose whether the governments had made these claims because (a) US and British leaders were misinformed by bad intelligence, (b) US and British leaders lied to provide a reason for invading Iraq, or (c) weapons of mass destructions (WMDs) might still be found. Responses were recoded on a threepoint scale where $1=$ WMDs might still be found (representing the least amount of government responsibility), $2=$ misinformation or bad intelligence (representing an intermediate attribution of responsibility), and $3=$ assertions that the governments lied about WMDs (representing the highest attribution of government responsibility). Previous research ties conservative political views to perceptions of the world as a dangerous place (see Jost et al., 2003). As such, conservatives should be more likely (as compared to liberals) to believe that WMDs exist because (a) weapons in Iraq might be dangerous to the security of the US and (b) may be viewed as a good justification for the war. In contrast, believing that the US government lied about the existence of WMDs implies that the weapons do not exist and, therefore, are not a danger. Without the justification of a threat to national security, people should be more likely to attribute responsibility for the war to the US government.

Support for the War Three items representing people's support for the Iraq war served as the dependent variable. The first item asked: "On the subject of Iraq, did the US make the right decision or the wrong decision to use military force against Iraq?" (Response options: "Right decision" and "Wrong decision"). The second item measured optimism for the outcomes anticipated for the Iraqi people: "Do you think the people of Iraq will be better off or worse off in the long run than 
they were now that Saddam Hussein has been removed from power by the US and its allies?" (Response options: "better off" and "worse off"). The third item asked whether participants thought that the war in Iraq had "helped the war on terrorism or hurt the war on terrorism." (Response options "helped", "hurt", "no effect"). We included only participants who responded "helped" or "hurt" to this question, because it is theoretically unclear how to interpret a "no effect" response in terms of support for the war in Iraq. Answers to each item were coded so that higher scores indicated more positive attitudes toward the war in Iraq and summed to form a single scale representing our dependent variable, support for the war (ranging from $0=$ low support, to $3=$ high support, $\alpha=.65$ ).

\section{Results}

To test our mediation hypothesis, we followed the three-step procedure using linear regression analyses suggested by Baron and Kenny (1986). According to this procedure, to obtain mediation (a) the independent variable (i.e., political orientation) needs to affect the proposed mediator (attributions of responsibility), (b) the independent variable must affect the dependent variable (support for the war), and (c) the mediator must influence the dependent variable while controlling for the influence of the independent variable. The influence of the independent variable should be smaller in the third compared to the second equation, which can be tested with a formula provided by Sobel (1982). Complete mediation occurs if the independent variable has no independent effect on the dependent variable when controlling for the mediator.

We predicted that attributions of government responsibility would mediate the relationship between political orientation and support for the war. We found that political orientation influenced the attributions of government responsibility for the war in Iraq, with greater conservatism predicting less perceived US government responsibility $(\beta=-.39, t(1,388)=-15.75, p<.001)$. In the second regression analysis, greater conservatism predicted more positive attitudes toward the war in Iraq $(\beta=.31, t(1,388)=12.23, p<.001)$. Finally, when controlling for the effect of perceived US government responsibility, the influence of political orientation on attitudes toward the war was substantively reduced, though still significant $(\beta=.13, t(1,387)=5.25, p<.001)$. However, attributions of responsibility were the dominant predictor of support for the war $(\beta=-.47, t(1,387)=-19.00$, $p<.001$, see Fig. 1). A Sobel (1982) test revealed that the attenuation of the direct relationship between political orientation and support for the war was highly significant, $(z=-12.88, p<.001)$.

Although the support for war items were highly correlated, these items were only proxies and did not ask directly about support for the war. As such, we conducted the mediation analysis for each item individually in case any one of the items appeared less related to war support. As expected, a similar pattern of results was obtained for each of the support for war items analyzed separately. 


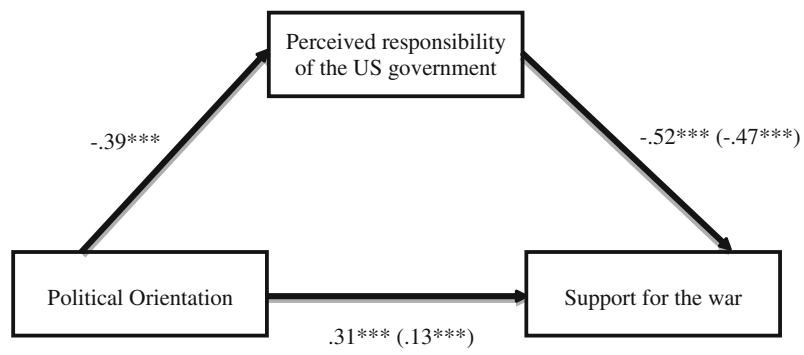

Fig. 1 Partial mediation of the effect of political orientation on support for the war in Iraq by attributions of responsibility of the US government for the war in Study 1

\section{Discussion}

We hypothesized that the effect of political orientation on support for the war in Iraq would be mediated by attributions regarding governmental responsibility for the war. Initial support for this hypothesis was found using data from the 2004 Pew Global Attitudes Project survey. The positive relationship between political orientation and support for the war in Iraq was partially mediated by the extent to which participants believed the US and British governments lied about Iraq possessing weapons of mass destruction. Conservatives expressed greater support for the war (as compared to liberals) but this effect was partially explained by the fact that conservatives were less likely to believe that the governments lied about Iraq possessing WMDs. In contrast, liberals were more likely to believe the US and British governments lied and subsequently showed less support for the war in Iraq.

Despite this evidence, the data from Study 1 had some limitations. Using data from a national survey allowed for a large and diverse sample, but required the use of pre-written questions. As such, the items were suitable proxies for our constructs of interest, but they were not perfect. First, concerning the mediator, attributions of government responsibility, we assumed that people who think the US and British governments lied about the existence of WMDs would attribute greater responsibility to these governments for the war. Because the existence of WMDs was the main justification for entering war, the absence of such evidence might lead people to attribute greater responsibility for the war to the governments. A more direct measurement of attributions of government responsibility would have been desirable. Second, the items representing the support for war construct were rather indirect. Indeed, these items concerned only one aspect of support: the general perceived consequences of the war in Iraq. Thus, more direct measures, assessing current opinions on the conflict and on how the US government should proceed, were necessary.

\section{Study 2}

Study 2 was developed to build upon and strengthen the findings of Study 1. Using scales to assess the target constructs of attributions of government responsibility and 
support for the war more directly, the second study attempted to replicate the mediation analysis in a different sample.

In addition, we extended our approach to investigate a further aspect of the attribution process proposed to mediate the effect of political orientation on support for the war. In the previous study, the focus was on attributions of the US and British government's responsibility for the war. Complementing this perspective, we expected that attributions concerning the responsibility of the pre-war Iraqi government would have corresponding effects. It was predicted that a more conservative political orientation would be associated with greater perceived responsibility for the war on the part of the pre-war Iraqi government, and that this would, in turn, lead to increased support for the war. In contrast, we predicted that liberals would perceive that the pre-war Iraqi government was less responsible for the war leading to decreased support for the war overall. Support for this double tracked hypothesis would provide further evidence that attribution processes play an important role in understanding why liberals and conservatives differ in their commitment to the war in Iraq.

\section{Method}

\section{Participants}

Forty-eight US citizens or permanent residents (26 were women and one participant did not indicate gender) completed an online-survey that was available from several publicly available Internet sites (see Appendix 1 for the full list of the websites). The ages of participants ranged from 14 to 67 years $(M=29.83, S D=13.95)$. Controlling for gender or age did not have any effect on the results and thus, will not be discussed further. The majority of participants identified themselves as Caucasian (68\%) and as students (71\%). Respondents came from 20 different states throughout the US. The majority of participants $(55 \%)$ reported that they or a close family member had served in the military and of those $16 \%$ said that the family member was currently or had previously served in Iraq. As a form of compensation for their time, participants were offered entry into a lottery for one of 4 gift certificates worth $\$ 50$ each.

\section{Procedure}

After providing informed consent, participants completed a measure of political orientation. The measure of participants' attributions about responsibility for the war in Iraq (the proposed mediator) was embedded among several items and was followed by the dependent measure, support for the war. Finally, participants were asked to provide demographic data.

\section{Materials}

Political Orientation Following previous research (e.g., Jost et al., 2007), political orientation was assessed with a one-item measure ("On the scale below, please 
select the number that best represents your political views/orientation"). Participants could respond on a scale ranging from 1 (extremely liberal) to 9 (extremely conservative).

Attributions of Responsibility The measures of perceived responsibility comprised two four-item scales; one focused on the US government, the other on the pre-war Iraqi government. An example of a statement focusing on the US government was: "The US government's motivations for going to war in Iraq had less to do with WMDs and more to do with obtaining oil." An example of a question focusing on the pre-war Iraqi government was: "Although the US did not immediately find WMDs Saddam Hussein was about to initiate a new WMD program" (see Table 1 for the full list of items). Participants indicated their level of agreement with the statements on a scale from 1 (strongly disagree) to 7 (strongly agree). All items were coded such that high scores reflected greater perceived responsibility of the US or the pre-war Iraqi government and two separate scales were formed, reflecting the perceived responsibility of the respective government $\left(\alpha_{\mathrm{US}}=.88, \alpha_{\mathrm{Iraq}}=.79\right)$. The order of items was determined randomly for each participant.

Support for the War Four items adapted from Agnew et al. (2007) were used to measure support for the war in Iraq. Items such as, "I want the war in Iraq to last as long as necessary," were presented and responses were made on a scale ranging from 1 (strongly disagree) to 7 (strongly agree). The items formed a reliable scale

Table 1 Initial Eigenvalues of factors and maximum-likelihood loadings of US and Iraqi government responsibility ratings in Study 2 after oblimin rotation

\begin{tabular}{lll}
\hline & Component \\
\cline { 2 - 2 } & 1 & 2 \\
& US & Iraqi \\
& Gov & Gov \\
\hline Initial Eigenvalues & 4.18 & 1.62 \\
The US government's motivations for going to war in Iraq had less to do with WMDs & .84 \\
and more to do with obtaining oil & .73 \\
The administration lied about the existence of WMDs in Iraq & .78 \\
After 9/11, the Bush administration needed a scapegoat and Iraq was a good target \\
The Bush administration's decision to go to war in Iraq was motivated by a desire to \\
finish the job the first Bush administration began \\
$\begin{array}{l}\text { Although the US did not immediately find WMDs Saddam Hussein was about to } \\
\text { initiate a new WMD program }\end{array}$ \\
$\begin{array}{l}\text { It is very likely that the Iraqi government was attempting to secure uranium from Niger } \\
\text { to make a nuclear bomb }\end{array}$ \\
$\begin{array}{l}\text { Saddam Hussein and his government posed a threat to American national security } \\
\text { WMDs have yet to be found in Iraq because the Iraqi government has done a good job } \\
\text { hiding or destroying them }\end{array}$ \\
\hline
\end{tabular}

Note. US Gov refers to "Perceived US government responsibility". Iraqi Gov refers to "Perceived prewar Iraqi government responsibility" 
( $\alpha=.77$, see Appendix 2 for the items). The order of items was randomly determined for each participant.

Results

We expected that attributions of responsibility focused on the US government and on the pre-war Iraqi government would represent separate, though negatively correlated, constructs. To test this, the eight attribution items were analysed in a factor analysis (with maximum-likelihood extraction and oblimin rotation) that converged in eight iterations. Items loading .40 or greater on the components with initial Eigenvalues greater than 1 were retained, yielding a two-component solution (see Table 1), accounting for $72.59 \%$ of the variance. As expected, two factors emerged; the first factor included the items concerning the US government while the second factor included the items referring to the pre-war Iraqi government. The factors were moderately correlated at $r=-.32$.

Next, we tested the hypothesis that attributions of government responsibility would mediate the relationship between political orientation and support for war. We followed the three-step procedure suggested by Baron and Kenny (1986) to test the mediation hypothesis. The US government responsibility model was tested first. As expected, political orientation predicted attributions of responsibility such that conservatism predicted less US government responsibility $(\beta=-.66, t(46)=$ $-5.93, p<.001)$. Consistent with predictions, the second step of analyses showed that political orientation was also related to support for the war $(\beta=.34$, $t(46)=2.45, p=.018)$. Finally, when controlling for the effect of perceived US responsibility, the influence of political orientation on support for the war was no longer significant $(\beta=-.01, t(45)=-.03, p=.978)$. Simultaneously, attributions of US government responsibility predicted support for the war $(\beta=-.52$, $t(45)=-3.10, p=.003$, see Fig. 2). The attenuation of the direct relationship between political orientation and support for the war was highly significant as indicated by a Sobel (1982) test, $(z=3.38, p<.001)$, suggesting full mediation. These results provide a conceptual replication of Study 1 with a different sample and different measures of responsibility and support for war.

Next, the mediation model testing pre-war Iraqi government attribution of responsibility was tested. As hypothesized, greater conservatism predicted higher

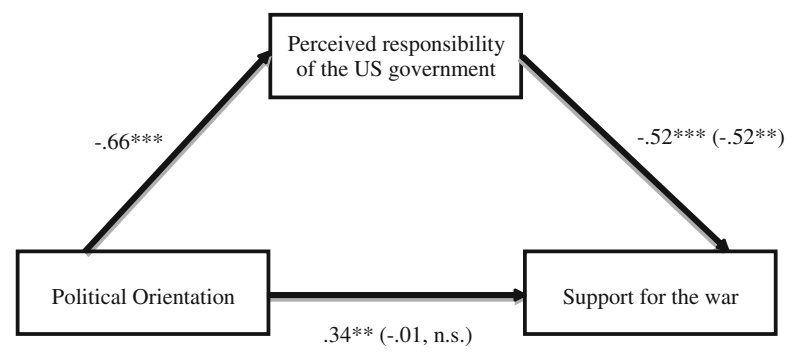

Fig. 2 Full mediation of the effect of political orientation on support for the war in Iraq by attributions of responsibility of the US government for the war in Study 2 


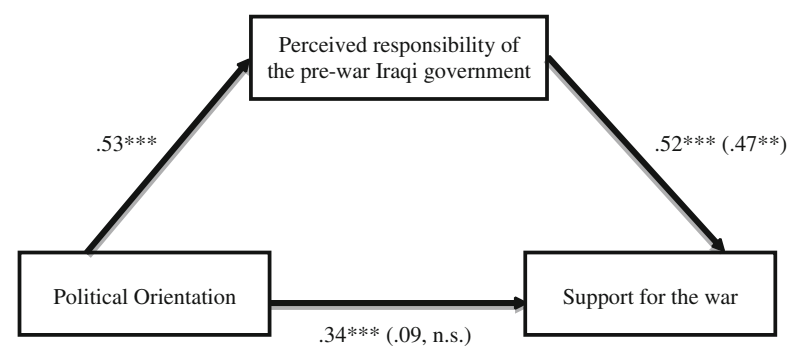

Fig. 3 Full mediation of the effect of political orientation on support for the war in Iraq by attributions of responsibility of the pre-war Iraqi government for the war in Study 2

scores on the Iraqi government responsibility measure $(\beta=.53, t(46)=4.26$, $p<.001)$. As shown in the first set of analyses, conservatives supported the war more strongly than did liberals $(\beta=.34, t(46)=2.45, p=.018)$. More importantly, when controlling for the effect of perceived Iraqi government responsibility, the direct influence of political orientation on support for the war became non-significant $(\beta=.09, t(45)=.62, p=.542)$. In contrast, pre-war Iraqi government responsibility (controlling for political orientation) predicted support for the war $(\beta=.47$, $t(45)=3.10, p=.003$, see Fig. 3).

Consistent with the US government responsibility analysis, the Sobel (1982) test indicated a highly significant mediation whereby the perceived responsibility of the pre-war Iraqi government mediated the relationship between political orientation and support for war $(z=2.94, p=.003)$. This result extends upon the previous findings and provides further support for the idea that attribution processes are important in understanding the different levels of commitment liberals and conservatives show for the war in Iraq.

It may be objected that, in principle, the reverse mediation might be possible as well. That is, conservatism might be associated with a tendency to directly support the war and this pro-war attitude would then be rationalized or justified post hoc by attributions of government responsibility. If this reasoning is correct, support for war should mediate the relationship between political orientation and attributions of responsibility. Although we find this reasoning less plausible from a theoretical perspective, we tested this possibility and found that the data did not fit the alternative explanation as well. Treating support for the war as a mediator had little effect on the relationship between political orientation and attributions of government responsibility (either US or Iraqi): Even when controlling for support for the war, political orientation strongly predicted attributions of US government responsibility $(\beta=$ $-.54, t(45)=-5.02, p<.001)$. Similarly, controlling for support for the war hardly affected the relationship between political orientation and perceived Iraqi pre-war attributions of responsibility $(\beta=.40, t(45)=3.31, p=.002)$. In sum, in line with our assumptions, there is strong evidence to suggest that beliefs about the US government's motivations and attributions of responsibility to the pre-war Iraqi government mediate the relationship between political orientation and support for the war in Iraq. There is little support for the explanation that these beliefs are merely a convenient post hoc justification for pro-war attitudes. 


\section{Discussion}

Studies 1 and 2 provide converging evidence for the proposed role of perceived government responsibility for the war. The studies suggest that beliefs about attributions of government responsibility produce changes in the level of support for the war. Mediation analyses provided stronger support for the current model compared to an alternative explanation. The effect of political orientation on support for the war in Iraq was fully mediated by attributions of responsibility for the war. However, political orientation remained a strong predictor of attributions of responsibility when controlling for support for the war.

One may argue that it is not political orientation that influences support for the war (via attributions of responsibility), but instead, that the causal pathway is reversed. That is, greater support for the war may lead to a shift in political orientation via lower levels of government blame. From a theoretical perspective, we deem this possibility unlikely. Political orientation is considered a rather stable construct (Sears, 1983), associated with several stable personality characteristics (Block \& Block, 2006) and determined by psychological needs (Jost et al., 2003) that may be rooted in genetic dispositions (Alford et al., 2005) and physiological traits (Oxley et al., 2008). However, both studies 1 and 2 used survey data and correlational analyses that do not allow for causal conclusions. To show that differences in the attributions of government responsibility for the war in Iraq can indeed cause changes in support for the war as hypothesized, a manipulation (rather than measurement) of attributions is required.

\section{Study 3}

In the final study, attributions of responsibility for the war were manipulated. More specifically, participants were led to believe that there was a consensus among political scholars that either (a) the US government misrepresented information about the actual threat posed by Iraq prior to the war or that (b) the pre-war Iraqi government represented a serious threat as a result of a WMD program. We expected that participants who were led to believe the Iraq government posed a serious threat to US security prior to the war would indicate stronger support for the war than participants who were led to believe that the US government misrepresented important information. This outcome would support the assumption of the causal mechanism inherent in our mediation model.

\section{Method}

\section{Participants}

One-hundred and fifty-seven US citizens and permanent residents (92 women) completed an online-study available from the same sites as Study 2. No participant from Study 1 participated in Study 2. Participants were randomly assigned to either a "US government responsibility" condition or a "Pre-war Iraqi government 
responsibility" condition. The ages of participants ranged from 15 to 77 years $(M=29.00, S D=12.59)$. Controlling for gender or age did not have any effect on the results and thus, will not be discussed further. The majority of participants identified themselves as Caucasians (81\%) and as students (62\%). As in Study 2, a majority of participants said that a close family member served in the military $(61 \%)$ and of those, $18 \%$ said that the family member had served or was currently serving in Iraq. Again, the chance to enter a lottery for one of four $\$ 50 \mathrm{gift}$ certificates was offered as a compensation for the participants' contributions to the research.

\section{Procedure}

After providing informed consent, participants read a short paragraph about the war, which they were told was a recent news report. Information in the "news report" manipulated participants' attributions of responsibility for the war in Iraq. Several questions, including the dependent variable, support for the war, followed the short paragraph. Demographic information was collected along with several one-sentence descriptions of the news report used to check that participants had read the manipulations. Finally, participants were carefully debriefed.

\section{Materials}

Manipulation of Attributions and Debriefing In the "US government responsibility" condition, participants read a "news article" stating that a conservative and a liberal think tank recently agreed that the US government largely misrepresented the intelligence information regarding the threat posed by Iraq prior to the invasion. In the "Pre-war Iraqi government responsibility" condition, participants read a "news article" stating that a conservative and a liberal think tank agreed that the Iraqi government, led by Saddam Hussein, had intentions to start WMD programs (see Appendix 3 for the full articles). At the end of the study, participants were informed that the "news reports" had been created by the researchers and that the current consensus among most news sources was that Iraq did not possess WMDs.

Support for the War The items assessing support for the war in Iraq were the same as those used in Study 2.

\section{Results and Discussion}

We restricted the data analyses to those participants who correctly identified the news report presented to them at the beginning of the survey. We reasoned that the manipulations could only be effective if participants actually read the texts; therefore, individuals who could not identify the correct description of the news report were excluded from analyses.

It was hypothesized that reading a news report suggesting that the US government (pre-war Iraqi government) was responsible for the war in Iraq would 
decrease (increase) support for the war. To test this hypothesis we ran a $t$-test with the condition as the independent variable and support for the war as the dependent variable. As expected, support for the war was higher in the "Pre-war Iraqi government responsible" condition $\left(M_{\text {Iraq }}=3.86, S D=1.67\right)$ than in the "US government responsible" condition $\left(M_{\mathrm{US}}=3.03, S D=1.75\right), t(103)=-2.47$, $p=.015$. This result suggests that attributions of responsibility for the war in Iraq can indeed directly influence support for the war, as hypothesized in our mediation model.

\section{General Discussion}

In this article, we investigated one mechanism by which individual differences in political ideology influence support for war. Drawing on the literature on political orientation as motivated social cognition (Jost et al., 2003), we hypothesized that liberals and conservatives would ascribe responsibility for the war in Iraq differently. More specifically, it was predicted that conservatives (vs. liberals) would attribute less responsibility to the US government and greater responsibility to the pre-war Iraqi government. Differing attributions were expected to explain why conservatives displayed stronger support for the war. Three studies supported these predictions. In Study 1, data from a large-scale public opinion survey revealed that attributions of responsibility to the US government partially mediated the relationship between political orientation and support for the war. Study 2 replicated this effect and showed that attributions of pre-war Iraqi government responsibility similarly mediated the relationship between political orientation and support for the war. Finally, using an experimental approach, Study 3 showed that manipulating attributions of responsibility can indeed cause changes in support for the war.

It is worthwhile pointing out several strengths of the present research. First, the data from Study 1 were collected in March 2004, only one year after the US occupation of Iraq. The same psychological mechanism appeared to mediate the influence of political orientation on support for the war in Iraq almost four years later, when the data for Study 2 were collected (late November 2007 to late January 2008). Results were also consistent in the face of (a) different operationalizations of the key constructs and (b) considerably different samples, recruited by a professional survey institute (Study 1) and via publicly available websites (Study 2). All samples, however, were clearly more heterogeneous both in terms of age and education than the usual student samples commonly employed in psychological experiments. Finally, it speaks to the validity of our theoretical analysis that it was possible to change participants' support for the war, at least to some extent, by manipulating attributions of government responsibility (Study 3), despite an extensive and enduring media-coverage of the war over the years.

We do not claim that attributions of responsibility are the single factor by which political orientation translates into varying degrees of support for a war. In fact, the motivated social cognition perspective on political orientation (Jost et al., 2003) offers several other related factors that lend themselves to similar hypotheses; these include, but are not limited to, dogmatism (Rokeach, 1956, 1960), the belief that the 
world is a dangerous place (Altemeyer, 1998), and the belief that the world is just (Lerner, 1980). Future research should start to disentangle both the joint and unique contributions of the various factors believed to be the antecedents of people's political orientation and the beliefs and attitudes associated with such positions.

To that end, future research may also begin to explore the underlying psychological pathways, which precede the mediators investigated in the current research (i.e., belief that the US government had good intentions, belief that the Iraqi government posed a threat to national security). It is likely that these mediators are influenced by different underlying psychological constructs. For example, it is possible that the relationship between political orientation and the belief in the WMD program is underpinned by the belief in a dangerous world. However, it may also be the case that other individual differences (for example, concern with ingroup loyalty versus concern with reciprocity and harm; Haidt \& Graham, 2007) also account for some of the variation in a belief that Iraq posed a serious threat. Future research will be needed to determine what portion of the variance each variable explains, and whether these relationships change in different contexts.

\section{Conclusion}

The war in Iraq has become a contentious issue in recent times. While previous research has shown that political orientation is related to support for the Iraq war, with more conservative views associated with greater support, there has been little research investigating the psychological processes explaining this relationship. Thus, the current research adds to the understanding of political orientation by showing that such views influence the way individuals attribute responsibility for the war. Different attribution styles are one factor that account for the relationship between political orientation and support for the war. Political orientation does matter, but attributions are crucial to the understanding of the psychological mechanisms that lead to its consequences.

Acknowledgments We would like to thank all members of the class "Political Ideology" of SISP 2007 as well as John Jost and Arie Kruglanski for their stimulating comments on this project.

\section{Appendix 1}

List of websites used for data collection in Study 2 and Study 3.

http://www.socialpsychology.org/expts.htm

http://genpsylab-wexlist.unizh.ch/

http://psych.hanover.edu/research/exponnet.html

http://umpsychology.sona-systems.com/

http://www.politicsforumpoliticalworld.com/

http://allsidespoliticalforums.com/

http://politicalhotwire.com/

http://www.4forums.com 


\section{Appendix 2}

Items used to assess support for the war in Studies 2 and 3, adapted from Agnew et al. (2007). Agnew et al. used questions referring to the "war on terror." These were changed to reference the "war in Iraq."

1. I want the war in Iraq to last as long as necessary.

2. I am committed to the US maintaining the war in Iraq as long as necessary.

3. I would not feel very upset if the war in Iraq were to fail. (reverse coded)

4. I am prepared for the war in Iraq to be waged over a long period of time.

\section{Appendix 3}

Manipulations of attributions for responsibility for the war in Study 3

\section{Condition "US Government Responsibility"}

Conservative and liberal experts agree that the US government misrepresented threat posed by Iraq. On March 19, 2003, President Bush announced the start of the Iraq war and urged the American people to give their support.

"My fellow citizens, at this hour American and coalition forces are in the early stages of military operations to disarm Iraq, to free its people and to defend the world from grave danger. On my orders, coalition forces have begun striking selected targets of military importance to undermine Saddam Hussein's ability to wage war. These are opening stages of what will be a broad and concerted campaign."

More than 4 years later, reports from the Heritage Foundation, a conservative think tank, and from the Institute for Policy Studies, a liberal think tank, agree that the US government largely misrepresented the intelligence information regarding the threat posed by Iraq. "Intelligence reports available prior to the start of the Iraq war strongly suggested that Saddam had no intention of restarting WMD programs", says Dr. Chris Evans, a national security expert from the Heritage Foundation. The former head of UN weapons inspections confirmed this statement shortly after the start of the Iraq war. By January 2005, "intelligence officials confirmed that the US had stopped searching for weapons of mass destruction in Iraq. There were no stockpiles of chemical or biological weapons at the time of the US-led invasion", says Dr. Paul Smith, an Iraq foreign policy specialist from the Institute for Policy Studies.

\section{Condition "Pre-war Iraqi Government Responsible"}

Conservative and liberal experts agree that former Iraqi government's WMD program intentions posed an international threat. On March 19, 2003, President Bush announced the start of the Iraq war and urged the American people to give their support. 
"My fellow citizens, at this hour American and coalition forces are in the early stages of military operations to disarm Iraq, to free its people and to defend the world from grave danger. On my orders, coalition forces have begun striking selected targets of military importance to undermine Saddam Hussein's ability to wage war. These are opening stages of what will be a broad and concerted campaign."

More than 4 years later, reports from the Heritage Foundation, a conservative think tank, and from the Institute for Policy Studies, a liberal think tank, agree that the former Iraqi government, led by Saddam Hussein, had intentions to start WMD programs. "Intelligence reports strongly suggest that Saddam Hussein's government posed a grave threat to international security at the time of the US-led invasion", says Dr. Chris Evans, a national security expert from the Heritage Foundation. The former head of UN weapons inspections confirmed this shortly after the start of the Iraq war. According to Dr. Paul Smith, an Iraq foreign policy specialist from the Institute for Policy Studies, "Saddam's government intended to start WMD programs-to stockpile chemical and biological weapons-at the time of the US-led invasion. American foreign policy had to address this imminent threat to international security."

\section{References}

Agnew, C. R., Hoffman, A. M., Lehmiller, J. J., \& Duncan, N. T. (2007). From the interpersonal to the international: Understanding commitment to the "War on Terror". Personality and Social Psychology Bulletin, 33, 1559-1571.

Alford, J. R., Funk, C. L., \& Hibbing, J. R. (2005). Are political orientations genetically transmitted? American Political Science Review, 99, 153-167.

Altemeyer, R. A. (1998). The other "authoritarian personality". In M. P. Zanna (Ed.), Advances in experimental social psychology (Vol. 30, pp. 47-91). New York: Academic Press.

Amodio, D. M., Jost, J. T., Master, S. L., \& Yee, C. M. (2007). Neurocognitive correlates of liberalism and conservatism. Nature Neuroscience, 10, 1246-1247.

Baron, R., \& Kenny, D. (1986). The moderator-mediator variable distinction in social psychological research: Conceptual, strategic, and statistical considerations. Journal of Personality and Social Psychology, 51, 1173-1182.

Block, J., \& Block, J. H. (2006). Nursery school personality and political orientation two decades later. Journal of Research in Personality, 40, 734-749.

Carney, D. R., Jost, J. T., Gosling, S. D., \& Potter, J. (2008). The secret lives of liberals and conservatives: Personality profiles, interaction styles, and the things they leave behind. Political Psychology, 29, 807-840.

Carroll, J., Perkowitz, W., Lurigio, A., \& Weaver, K. (1987). Sentencing goals, causal attributions, and personality. Journal of Personality and Social Psychology, 52, 107-118.

Converse, P. E. (1964). The nature of belief systems in mass publics. In D. E. Apter (Ed.), Ideology and discontent (pp. 206-261). New York: Free Press.

Cozzarelli, C., Wilkinson, A. V., \& Tagler, M. J. (2001). Attitudes toward the poor and attributions for poverty. Journal of Social Issues, 57, 207-227.

Gallup Poll. (2003, March 24-25). Gallup's pulse of democracy. The war in Iraq. Retrieved July 25, 2008, from http://www.gallup.com/poll/1633/Iraq.aspx

Gallup Poll. (2008, April 18-20). Gallup's pulse of democracy. The war in Iraq. Retrieved July 25, 2008, from http://www.gallup.com/poll/1633/Iraq.aspx 
Grote, N. K., Frieze, I. H., \& Schmidt, L. C. (1997). Political attitudes and the Vietnam War: A study of college-educated men of the Vietnam Generation. Journal of Applied Social Psychology, 27, 16731693.

Haidt, J., \& Graham, J. (2007). When morality opposes justice: Conservatives have moral intuitions that liberals may not recognize. Social Justice Research, 20, 98-116.

Jost, J. T. (2006). The end of the end of ideology. American Psychologist, 61, 1-20.

Jost, J. T., Glaser, J., Kruglanski, A. W., \& Sulloway, F. (2003). Political conservatism as motivated social cognition. Psychological Bulletin, 129, 339-375.

Jost, J. T., Napier, J. L., Thorisdottir, H., Gosling, S. D., Palfai, T. P., \& Ostafin, B. (2007). Are needs to manage uncertainty and threat associated with political conservatism or ideological extremity? Personality and Social Psychology Bulletin, 33, 989-1007.

Jost, J. T., Nosek, B. A., \& Gosling, S. D. (2008). Ideology: Its resurgence in social, personality, and political psychology. Perspectives on Psychological Science, 3, 126-136.

Lerner, M. J. (1980). The belief in a just world: A fundamental delusion. New York: Plenum Press.

Lipset, S. (1960). Political man. Garden City: Doubleday.

Oxley, D. R., Smith, K. B., Alford, J. R., Hibbing, M. V., Miller, J. L., Scalora, M., et al. (2008). Political attitudes vary with physiological traits. Science, 321, 1667-1670.

Pellegrini, R. J., Queirolo, S. S., Monarrez, V. E., \& Valenzuela, D. M. (1997). Political identification and perceptions of homelessness: Attributed causality and attitudes on public policy. Psychological Reports, 80, 1139-1148.

Pew Global Attitudes Project. (2003). America's image further erodes, Europeans want weaker ties; but post-war Iraq will be better off, most say. Retrieved July 11, 2008, from http://pewglobal.org/ datasets/signup.php?DocID=143

Pew Global Attitudes Project. (2004). A year after Iraq war. Retrieved July 11, 2008, from http:// pewglobal.org/datasets/signup.php?DocID $=234$

Pratto, F., Sidanius, J., Stallworth, L. M., \& Malle, B. F. (1994). Social dominance orientation: A personality variable predicting social and political attitudes. Journal of Personality and Social Psychology, 67, 741-763.

Reuters. (2008). Iraq war hits U.S. economy: Nobel winner. Retrieved July 15, 2008, from http:// www.reuters.com/article/topNews/ idUSN2921527420080302? feedType=RSS\&feedName=topNews\&sp=true

Rokeach, M. (1956). Political and religious dogmatism: An alternative to the authoritarian personality. Psychological Monographs, 70(18, Whole No. 425), 43.

Rokeach, M. (1960). The open and closed mind. New York: Basic Books.

Sears, D. O. (1983). The persistence of early political predispositions: The roles of attitude object and life stage. In L. Wheeler (Ed.), Review of personality and social psychology (pp. 79-116). Beverly Hills: Sage.

Shils, E. A. (1958). Ideology and civility: On the politics of the intellectual. Sewanee Review, 66, 450480.

Skitka, L. J., McMurray, P. J., \& Burroughs, T. E. (1991). Willingness to provide post-war aid to Iraq and Kuwait: An application of the contingency model of distributive justice. Contemporary Social Psychology, 15, 179-188.

Skitka, L. J., Mullen, E., Griffin, T., Hutchinson, S., \& Chamberlin, B. (2002). Dispositions, scripts, or motivated correction? Understanding ideological differences in explanations for social problems. Journal of Personality and Social Psychology, 83, 470-487.

Skitka, L. J., \& Tetlock, P. E. (1993). Providing public assistance: Cognitive and motivational processes underlying liberal and conservative policy preferences. Journal of Personality and Social Psychology, 65, 1205-1223.

Sniderman, P. M., Hagen, M. G., Tetlock, P. E., \& Brady, H. E. (1986). Reasoning chains: Causal models of policy reasoning in mass publics. British Journal of Political Science, 16, 405-430.

Sobel, M. E. (1982). Asymptotic confidence intervals for indirect effects in structural equations models. In S. Leinhart (Ed.), Sociological methodology 1982 (pp. 290-312). San Francisco: Jossey-Bass.

World Public Opinion. (2006). Iraq: The separate realities of Republicans and Democrats. Retrieved July 15, 2008, from http://www.worldpublicopinion.org/pipa/articles/brunitedstatescanadara/186.php? nid=\&id=\&pnt $=186 \& l b=$ brusc 